\title{
Short communication \\ Tailored targeted therapy for all: a realistic and worthwhile objective against
}

\author{
Kathleen I Pritchard
}

Sunnybrook Odette Cancer Centre, Sunnybrook Health Sciences Centre, University of Toronto, 2075 Bayview Avenue, Toronto, ON, Canada M4N 3M5

Corresponding author: Kathleen I Pritchard, kathy.pritchard@sunnybrook.ca

Published: 18 December 2009

This article is online at

http://breast-cancer-research.com/supplements/11/S3/S8
Breast Cancer Research 2009, 11(Suppl 3):S8

(doi:10.1186/bcr2427)

(c) 2009 BioMed Central Ltd

\section{Introduction}

Targeted therapy for breast cancer was actually used, albeit unwittingly, as early as the late 1800s. Beatson first surgically removed the ovaries of women to treat metastatic breast cancer in 1896 [1], while Schinzinger recommended ovarian irradiation as adjuvant therapy in 1889 [2]. Ovarian ablation and subsequently diethylstilbestrol were initially used to treat breast cancer without knowing the target to which they were directed. More than 50 years later Jensen and Jacobson discovered the oestrogen receptor (ER) [3], which was subsequently understood to be the target or partial target of these endocrine approaches.

It is now known that women whose tumours are ER-negative and progesterone receptor $(\mathrm{PgR})$-negative have less than a $5 \%$ chance of responding to endocrine therapies, while those whose tumours are ER-positive and/or PgR-positive have a chance of response of somewhere between 40 and $70 \%$. It was believed that having both receptors positive improved the response rate or benefit from adjuvant endocrine therapy for many years, but is now felt that the ER serves as the major predictive factor. The $\mathrm{PgR}$ is felt to give some prognostic value but not to be associated with better response to endocrine therapy in the adjuvant or the metastatic setting [4] (R. Peto, personal communication).

For a number of years there was controversy about whether tamoxifen might be effective in ER-negative as well as ERpositive patients. Even the large Oxford Overview [5] did not initially display this clearly for some long time, and it was in fact from other studies with carefully controlled biomarkers that the role of ER in predictory effectiveness became more clear $[6,7]$. This experience provides lessons for the future, in that large meta-analyses in which markers may have been measured by a variety of methods may not be the best way of sorting out these matters. Even today there is ongoing controversy regarding the role of the ER and response to chemotherapy. It is generally felt that highly ER-positive patients may respond less well to chemotherapy. Certainly high ER and PgR levels have an inverse link to proliferative indices such as $\mathrm{Ki}-67$, which tend to predict more strongly for response to chemotherapy.

We now have the 21-gene OncotypeDX recurrence score that may be used as a continuous variable both to predict benefit from tamoxifen and to predict response from those treated with tamoxifen [8-11]. It has also been shown that the OncotypeDX recurrence score correlates more strongly with outcome in tamoxifen-treated patients than the Adjuvant online program and that the OncotypeDX recurrence score is also predictive of local recurrence in tamoxifen-treated patients [12]. The OncotypeDX assay is now being studied in the TAILORx study - in which women with a recurrence score $<11$ will receive hormonal therapy only and women with a recurrence score $>25$ will receive hormonal therapy and chemotherapy, while women with an intermediate recurrence score of 11 to 25 will be randomized to receive hormonal therapy alone with or without chemotherapy. The OncotypeDX recurrence score may serve as a prognostic and predictive factor; that is, predicting both the chance of recurrence and the potential efficacy of hormonal and/or chemotherapy. Being a combination of 21 genes, however, the variable is not really a target as such. Furthermore, the assay is constituted mainly of genes representing ER, proliferation and HER2.

The HER2 protein and gene proved not only to have prognostic value $[13,14]$ but also to be a genuine target that could be targeted for a specific response. The first treatment directed toward the HER2 oncoprotein was trastuzumab (Herceptin), a humanized monoclonal anti-HER2 antibody that produced $15 \%$ response rates as a single agent in

$E R=$ oestrogen receptor $\mathrm{PgR}=$ progesterone receptor. 
HER2-positive patients [15] and significantly added to progression-free survival and overall survival in women with metastatic disease treated with several types of chemotherapy [16]. Concordance between local and central laboratories in determining HER2 has been problematic, and some patients who have been declared HER2-negative on central review in large trials have nonetheless received benefit from Herceptin. This is being further explored. Although HER2 is clearly a bona fide target for anti-HER2 therapies such as Herceptin, lapatinib (Tykerb) and others, problems with its measurement and with the fact that only $\sim 15 \%$ of those who are HER2-positive actually seem to benefit remain a challenge. Interestingly HER2 has an inverse relationship with the ER and PgR [17]. HER2 is also involved in endocrine resistance $[18,19]$. Endocrine resistance may in part be reversible by adding a HER2-targeted agent, as has been done in the TANDEM trial [20].

Many of us have attempted to use HER2 measurements to predict differential response to anthracyclines, and this seems to be reliable although not all data are consistent [2123]. Some feel that HER 2 is predictive in this setting only because it is located on the topoisomerase $\| \alpha$ gene of chromosome 17, topoisomerase II $\alpha$ being an enzyme that is directly involved in the mechanism of action of anthracyclines against human cancers. Topoisomerase Il $\alpha$ gene amplification and HER2/neu gene amplification and protein overexpression are closely related, and each predict for responsiveness to anthracyclines in some randomized trials comparing anthracycline-containing versus nonanthracyclinecontaining regimens [21,24]. Furthermore, topoisomerase II protein overexpression also appears to predict for differential anthracycline benefit, although it seems less closely related to topoisomerase Il $\alpha$ overexpression and/or HER2/neu [25].

A meta-analysis of phase III trials evaluating the predictive value of HER2 and topoisomerase Il $\alpha$ in early breast cancer patients treated with cyclophosphamide, methotrexate and 5-FU (CMF) versus anthracycline-based adjuvant therapy did not show a strongly statistically significant predictive value [26], particularly when the large British NEAT and BR9601 studies were included (J. Bartlett, personal communication). Some investigators now believe that chromosome 17 polysomy is a more appropriate predictive marker [27,28]. The predictive value of these particular gene and protein changes remains to be clarified but it seems unlikely that they actually represent targets in the same way as HER2 is a target of Herceptin.

Additionally, targeted anti-HER2 agents such as lapatinib were meant to be effective against HER1 and HER2 overexpressing tumours but have proved to affect only individuals with HER2-positive tumours. Newer drugs such as bevacizumab - an antivascular endothelial growth factor antibody are effective, but one cannot find a target that selects subgroups of patients in whom it is more valuable [29].
Some targeted therapies, including the endocrine therapies and trastuzumab, are therefore clearly available and can be directed in effective, albeit less than perfect, ways towards specified and relatively well measured targets. Some of the new biologics or so-called targeted agents such as bevacizumab and lapatinib, however, are not as clearly directed towards their targets as might have been initially predicted. I would therefore conclude that tailored targeted therapy for all may be worthwhile but is not yet realistic.

\section{Competing interests}

The author declares that they have no competing interests.

\section{Acknowledgement}

This article has been published as part of Breast Cancer Research Volume 11 Suppl 3 2009: Controversies in Breast Cancer 2009. The full contents of the supplement are available online at http://breastcancer-research.com/supplements/11/S3.

\section{References}

1. Beatson GT: On the treatment of inoperable cases of carcinoma of the mamma: suggestions for a new method of treatment with illustrative cases. Lancet 1896, 2:104-107.

2. Schinzinger A: Ueber carcinoma mammae. Verh Dtsch Ges Chir 1889, 18:28-29.

3. Jensen EV, Jacobson $\mathrm{HI}$ : Fate of steroid estrogens in target tissues. In Biological Activities of Steroids in Relation to Cancer. Edited by Pincus G, Vollmer EP. New York: Academic Press; 1960:161-178.

4. Early Breast Cancer Trialists' Collaborative Group: Effects of chemotherapy and hormonal therapy for early breast cancer on recurrence and 15-year survival: an overview of the randomised trials. Lancet 2005, 365:1687-1717.

5. Early Breast Cancer Trialists' Collaborative Group: Tamoxifen for early breast cancer: an overview of the randomized trials. Lancet 1998, 351:1451-1467.

6. Fisher B, Costantino J, Redmond C, Poisson R, Bowman D, Couture J, Dimitrov NV, Wolmark N, Wickerham DL, Fisher ER, Margolese R, Robidoux A, Shibata H, Terz J, Paterson AHG, Feldman MI, Farrar W, Evans J, Lickley HL, Ketner M: A randomized clinical trial evaluating tamoxifen in the treatment of patients with node-negative breast cancer who have estrogen-receptor-positive tumors. N Engl J Med 1989, 320:479484.

7. Fisher B, Redmond C, Brown A, Fisher ER, Wolmark N, Bowman D, Plotkin D, Wolter J, Bornstein R, Legault-Poisson S: Adjuvant chemotherapy with and without tamoxifen in the treatment of primary breast cancer: 5 year results from the National Surgical Adjuvant Breast and Bowel Project Trial. J Clin Oncol 1986, 4:459-471.

8. Paik S, Shak S, Tang G, Kim C, Baker J, Cronin M, Baehner FL, Walker MG, Watson D, Park T, Hiller W, Fisher ER, Wickerham $\mathrm{DL}$, Bryant J, Wolmark N: A multigene assay to predict recurrence of tamoxifen-treated, node-negative breast cancer. $N$ Engl J Med 2004, 351:2817-2826.

9. Paik S, Shak S, Tang G, Kim C, Baker J, Cronin M, Watson D, Bryant J, Costantino J, Wolmark N: Expression of the 21 genes in the Recurrence Score assay and tamoxifen clinical benefit in the NSABP study B-14 of node negative, estrogen receptor positive breast cancer [meeting abstracts]. J Clin Oncol 2005, 23:510.

10. Habel LA, Quesenberry CP, Jacobs MK, Blick NT, Greenberg D, Alexander C, Baker J, Walker M, Watson D, Shak S: A large case-controlled study of gene expression and breast cancer death in the North California Kaiser Permanente population [abstract 3019]. Breast Cancer Res Treat 2004, 88:S118.

11. Paik S, Shak S, Tang G, Kim C, Kim WK, Baker J, Cronin M, Walker M, Bryant J, Wolmark N: Risk classification of breast cancer patients by the recurrence score assay: comparison to guidelines based on patient age, tumor size and tumor grade [abstract 104]. Breast Cancer Res Treat 2004, 88:S21. 
12. Mamounas E, Tang G, Bryant J, Paik S, Shak S, Costantino J, Watson D, Wickerham DL, Wolmark N: Association between 21-gene recurrence score assay and risk of locoregional failure in node-negative, ER-positive breast cancer: results from NSABP B-14 and NSABP B-20 [abstract 29]. Breast Cancer Res Treat 2005, 94:S16.

13. Slamon DJ, Godolphin W, Jones LA, Holt JA, Wong SG, Keith DE, Levin WJ, Stuart SG, Udove J, Ullrich A, et al.: Studies of the Her-2/neu proto-oncogene in human breast and ovarian cancer. Science 1989, 244:707-712.

14. Andrulis IL, Bull SB, Blackstein ME, Sutherland D, Mak C, Sidlofsky S, Pritzker KP, Hartwick RW, Hanna W, Lickley L, Wilkinson R, Qizilbash A, Ambus U, Lipa M, Weizel H, Katz A, Baida M, Mariz S, Stoik G, Dacamara P, Strongitharm D, Geddie W, McCready D: neu/erbB-2 amplification identifies a poor-prognosis group of women with node-negative breast cancer. Toronto Breast Cancer Study Group. J Clin Oncol 1998, 16: 1340-1349.

15. Vogel CL, Cobleigh MA, Tripathy D, Gutheil JC, Harris LN, Fehrenbacher L, Slamon D J, Murphy M, Novotny WF, Burchmore M, Shak S, Stewart SJ, Press M: Efficacy and safety of trastuzumab as a single agent in first-line treatment of HER2overexpressing metastatic breast cancer. J Clin Oncol 2002, 22:719-726.

16. Slamon DJ, Leyland-Jones B, Shak S, Fuchs H, Paton V, Bajamonde A, Fleming TR, Eiermann W, Norton L, Wolter J, Pegram M $D$, Baselga J: Use of chemotherapy plus a monoclonal antibody against Her2 for metastatic breast cancer that overexpresses Her2. N Engl J Med 2001, 344:783-792.

17. Konecny G, Pauletti G, Pegram M, Untch M, Dandekar S, Aguilar Z, Wilson CJ, Rong HM, Bauerfeind I, Felber M, Wang HJ, Beryt $M$, Seshadri R, Hepp H, Slamon DJ: Quantitative association between HER-2/neu and steroid hormone receptors in hormone receptor-positive primary breast cancer. I Natl Cancer Inst 2003, 95:142-153.

18. Ellis $\mathrm{M}$ : Overcoming endocrine therapy resistance by signal transduction inhibition. Oncologist 2004, 9:20-26.

19. De Laurentiis M, Arpino G, Massarelli E, Ruggiero A, Carlomagno $C$, et al.: HER2 as predictive marker of resistance to endocrine treatment for advanced breast cancer: a meta-analysis of published studies [abstract 233]. Breast Cancer Res Treat 2002, 76:S68.

20. Kaufman B, Mackey JR, Clemens MR, Bapsy PP, Vaid A, Wardley A, Tjulandin S, Jahn M, Lehle M, Feyereislova A, Revil C, Jones A: Trastuzumab plus anastrozole versus anastrozole alone for the treatment of postmenopausal women with human epidermal growth factor receptor 2-positive, hormone receptor-positive metastatic breast cancer: results from the randomized phase III TAnDEM study. J Clin Oncol 2009, in press.

21. Pritchard KI, Shepherd LE, O'Malley FP, Andrulis IL, Tu D, Bramwell VH, Levine M: HER2 and responsiveness of breast cancer to adjuvant chemotherapy. $N$ Engl J Med 2006, 354: 2103-2111.

22. Gennari $A$, Sormani $M$, Puntoni M: A pooled analysis on the interaction between Her-2 expression and responsiveness of breast cancer ot adjuvant chemotherapy [abstract 41]. $\mathrm{Br}$ Cancer Res Treat 2006, 100:19.

23. Bartlett JMS, Munro A, Cameron DA, Thomas J, Prescott R, Twelves C: Type I receptor tyrosine kinase profiles identify patients with enhanced benefit from anthracyclines in the BR9601 adjuvant breast cancer chemotherapy trial. J Clin Oncol 2008, 26:5027-5035.

24. O'Malley F, Chia S, Tu D, Shepherd L, Levine M, Bramwell V, Andrulis I, Pritchard K I: Topoisomerase II alpha and responsiveness of breast cancer to adjuvant chemotherapy. $J$ Natl Cancer Inst 2009, 101:644-650.

25. Pritchard KI, Messersmith H, Elavathil L, Trudeau M, O'Malley F, Dhesy-Thind B: Her-2 and topoisomerase II as predictors of response to chemotherapy. J Clin Oncol 2008, 26:1-9.

26. Di Leo A, Isola J, Piette F, Ejlertsen B, Pritchard KI, Bartlett JMS, Desmedt C, Larsimont D, Tanner M, Mouridsen H, O'Malley F, Twelves C, Cardoso F, Poole C, Piccart-Gebhart MJ, Buyse M: A meta-analysis of phase III trials evaluating the predictive value of HER2 and topoisomerase II alpha in early breast cancer patients treated with CMF or anthracycline-based adjuvant therapy [abstract 705]. Breast Cancer Res Treat 2008, 107:24.
27. Reinholz MM, Jenkins RB, Hillman DW, Lingle W, Davidson NE, Martino S, Kaufman PA, Perez EA: The clinical significance of poly 17 in the HER2 and N98431 intergroup adjuvant trastuzumab trial [abstract 36]. Breast Cancer Res Treat 2007, 107:S11.

28. Bartlett JMS, Munro A, Dunn J, Hiller L, Jordan S, Twelves C, Cameron DA, Thomas J, Campbell F, Rea DW, Provenzano E, Pharoah PD, Caldas C, Earl H, Poole CJ: Chromosome 17 polysomy $(\mathrm{CH} 17)$ as a predictor of anthracycline response: emerging evidence from the UK NEAT adjuvant breast cancer trial [abstract 45]. Breast Cancer Res Treat 2008, 107:20.

29. Miller K, Wang M, Gralow J, Dickler M, Cobleigh M, Perez EA, Shenkier T, Cella D, Davidson NE: Paclitaxel plus bevacizumab versus paclitaxel alone for metastatic breast cancer. $N$ Engl J Med 2007, 357:2666-2676. 